\title{
The role of intra-luteal factors in the control of the porcine corpus luteum
}

\author{
J. Gadsby, L. Rose, R. Sriperumbudur and Z. Ge \\ Department of Molecular Biomedical Sciences, College of Veterinary Medicine, North Carolina State \\ University, Raleigh, NC, USA
}

In this paper we review three intra-luteal factors and their roles in the corpus luteum (CL). Insulin-like growth factor (IGF)-I, together with its receptor and IGF-binding proteins (IGFBPs), represent an important control system in the CL. IGF-I is a product of small luteal cells and has steroidogenic (i.e. luteotrophic) actions on large luteal cells via the type I receptor, while IGFBPs (e.g. BP-2 and 3; small cells) generally inhibit IGF-Is actions. IGF-I is particularly important in early $\mathrm{CL}$ development (up to day 7 of the oestrous cycle) in the pig. Tumour necrosis factor (TNF)- $\alpha$ is a product of luteal macrophages that infiltrate CLs in increasing numbers as the cycle progresses. TNF- $\alpha$ has been shown to play an important role in luteolysis, but we hypothesise that in the pig, this factor plays an additional role during the mid-lutea! phase (days 7-13) in promoting the acquisition of luteal sensitivity to the luteolytic actions of prostaglandin (PG) $\mathrm{F}_{2 \alpha}$ (= luteolytic sensitivity; LS). Endothelin (ET)-1 is a product of (luteal) endothelial cells, and along with its receptors (ET and $\mathrm{ET}_{\mathrm{B}}$ ) and endothelin-converting enzyme (ECE)-1, represent an intra-luteal system that also plays a role in luteolysis, in association with $\mathrm{PGF}_{2 \alpha}$. Since TNF- $\alpha$ induces endothelial cells to secrete ET-1, we hypothesise that ET1 mediates the sensitising effects of TNF- $\alpha$ on the porcine $C L$ during the mid-luteal phase (days 7-13). Finally, we hypothesise that TNF- $\alpha$ and/or ET-1 act to up-regulate luteal protein kinase C (e.g. isoforms BII and $\varepsilon$ ) activity and thereby sensitises luteal cells to PGF $_{2 \alpha}$.

\section{Introduction}

Studies carried out almost 40 years ago clearly demonstrated that porcine corpora lutea (CLs) are capable of developing, functioning and regressing in the absence of pituitary gonadotrophins (Anderson et al., 1967). Thus, our research focus has been on the role of intra-luteal factors in controlling these important processes. We first examined the insulin-like growth factor, IGF-I, as a luteotrophic factor in early luteal development and function. In more recent studies, we have investigated tumour necrosis factor (TNF)- $\alpha$ and endothelin (ET)-1, both of which are involved in luteolysis. However, we explored these factors for their possible roles in the acquisition of luteal sensitivity to $\mathrm{PGF}_{2 \alpha}$ (luteolytic sensitivity $=\mathrm{LS}$ ). In this chapter, the 
literature documenting the roles of IGF-I, TNF- $\alpha$ and ET-1 in the CL is reviewed, and we present data and models to illustrate our hypotheses concerning the roles of these intra-luteal factors in the control of the porcine $\mathrm{CL}$.

\section{Insulin-like growth factor}

IGF-I

IGF-I mRNA expression has been demonstrated in the CLs of several species including the pig (see Miller et al., 2003 for refs). In the cow IGF-I mRNA levels were greatest on days 1-4 of the cycle and then declined (Einspanier et al., 1990; Schams et al., 2002). In ovine CLs, IGF-I mRNA expression increased from days 3-6 and remained unchanged for the rest of the cycle (Juengel et al., 1997). IGF-I peptide was identified in both small and large bovine luteal cells and showed little variation during the oestrous cycle (Amselgruber et al., 1994).

In our studies in the pig, we have shown that IGF-I mRNA expression was higher in small than in large, luteal cells (Gadsby et al., 1996a; Fig. 1A), and was greater on days 4-6 than on days 10-16 of the oestrous cycle (Gadsby et al., 1996a). Intra-luteal levels of IGF-I peptide were also significantly elevated on day 4 versus $7-16$ of the oestrous cycle (Ge et al., 2003).

$I G F-I R$

IGF-I exerts its biological effects via the type I IGF receptor (IGF-IR) (Valentinis and Baserga, 2001). IGF-IR has been detected in the CLs of the several species (see Miller et al., 2003 for refs). In the bovine CL, IGF-IR mRNA expression was greatest on days 1-4 than on later stages of the oestrous cycle (Schams et al., 2002).

In the pig, IGF-IR mRNA expression was significantly greater in large, compared with small, luteal cells, and was lowest in CLs during the early oestrous cycle, increasing to reach maximal levels on day 16. IGF-IR protein concentrations were also greater in large luteal cells (3-85 fold compared with small luteal cells), and were highest during the early (days 4-10) compared with later stages (day 12-16) of the cycle (Ge et al., 2000).

\section{|CF-I actions}

IGF-I stimulated luteal progesterone secretion in vitro in several species including the pig (see Miller et al., 2003 for refs; Ptak et al., 2003). IGF-I also increased luteal progesterone secretion when administered in vivo in the cow (Sauerwein et al., 1992). IGF-I acts to increase luteal steroidogenesis by elevating steroidogenic acute regulatory (StAR) protein concentrations (Balasubramanian et al., 1997; Mamluk et al., 1999).

We examined the steroidogenic response of CLs to IGF-I at different stages of the oestrous cycle in vitro and in vivo (Miller et al., 2003). Porcine luteal cells were cultured with increasing doses of IGF-I or the IGF-I agonist, long- $R_{3}-I G F-I$, and the data obtained indicated that: 1) steroidogenesis was dose-dependently increased by IGF-I or long- $R_{3}-\mid G F-1$ in large, but not small, luteal cells (confirming Yuan and Lucy, 1996); 2) luteal cells taken only from days 4 and 7 of the cycle, were sensitive to IGF-I and long-R -IGF-I (confirmed by Ptak et al., 2003); and 3) the actions of IGF-I on the porcine CL were mediated via the PI-3 kinase pathway. Furthermore, IGF-I infused locally into the ovarian vasculature in vivo on days 6-7 of the oestrous cycle, acutely (1-2 hour) stimulated progesterone secretion. 

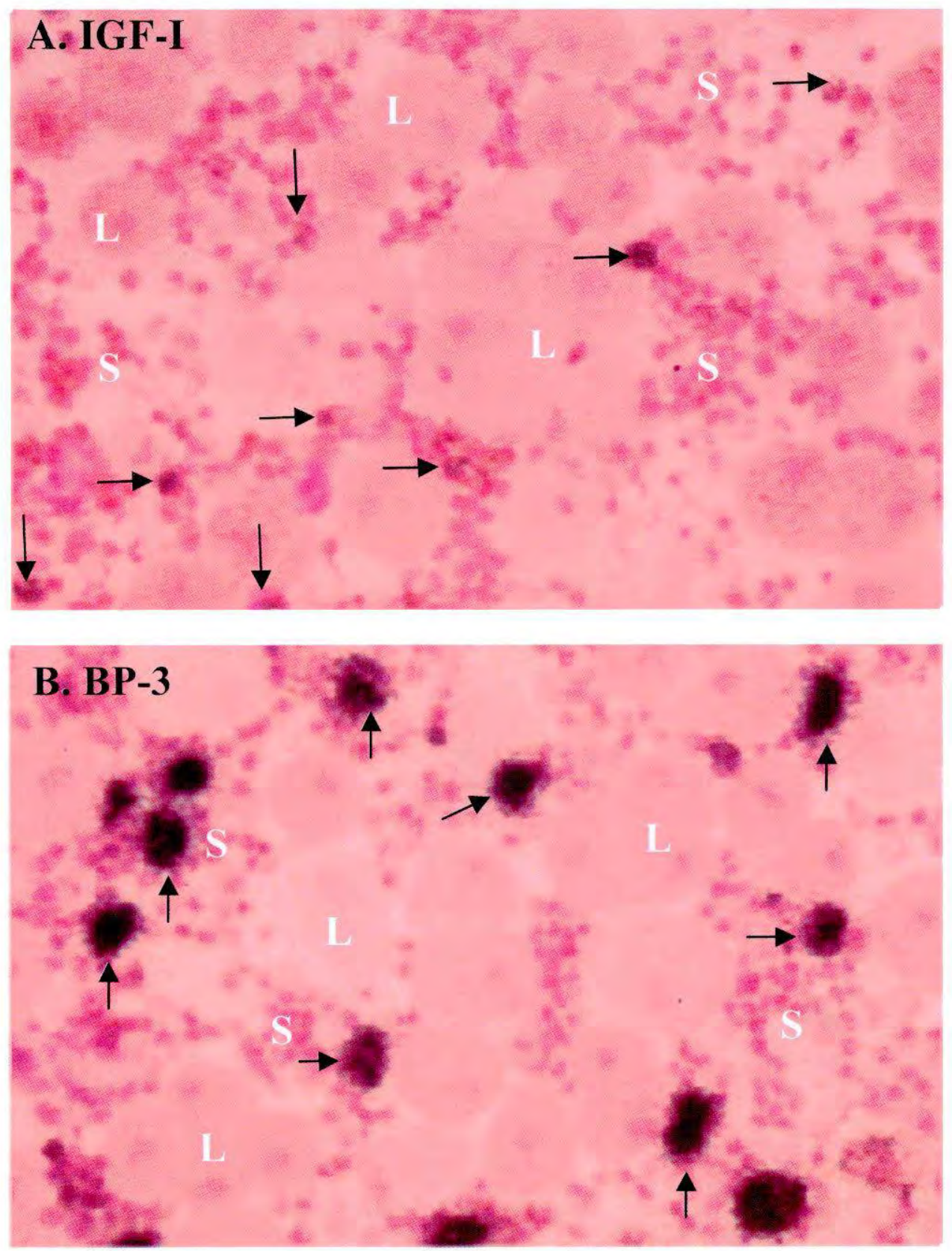

Fig. 1 Localisation of IGF-I and IGFBP-3 mRNAs in porcine luteal cells by in situ hybridisation. CLs were collected on day 7 of the oestrous cycle, enzyme-dissociated and centrifuged onto slides. A. IGF-I (40X magnification), B. IGFBP-3 (40X). Small cells are the primary sites of mRNA expression for IGF-I and BP-3. Arrows indicate positively labelled cells. $\mathrm{L}=$ large luteal cells (large pale staining cytoplasm with dark pink nuclei), $\mathrm{S}=$ small luteal cells (steroidogenic or non-steroidogenic). 
IGFBPS

The IGFBPs are thought to modulate the biological actions of the IGFs (Baxter, 2000) and there are several reports of mRNA and protein expression in the CL of IGFBPs 1-5 (see Ge et al., 2003 for refs). In the bovine CL, IGFBP-3 concentrations were highest during the early oestrous cycle (Brown and Braden, 2001; Schams et al., 2002). IGFBP-3 specifically, was shown to localise to endothelial cells of the luteal microvasculature in rodent, primate and porcine CLs (see Ge et al., 2003 for refs; Wandji et al., 2000).

In our studies in the pig CL, we have demonstrated IGFBPs 2-5 mRNA (Gadsby et al., 1996a; Fig. 1B) and protein (Nicholson et al., 1999; Ge et al., 2003) expression, predominantly in small luteal cells (Gadsby et al., 1996a; Fig. 1B). While the concentrations (protein) of IGFBPs 2,4 , and 5 did not vary significantly during the oestrous cycle, IGFBP-3 concentrations were at their highest on days 4 and 7 (Ge et al., 2003). We also demonstrated dose-dependent inhibitory effects of IGFBP-3 on IGF-I stimulated progesterone secretion (Ge et al., 2003). Furthermore, luteal cells cultured with an IGFBP-3 antibody displayed dose-dependent stimulation of steroidogenesis, further supporting an inhibitory role for IGFBP-3 in the porcine CL (Ge et al., 2003). IGFBP-2 and -3 show similar inhibitory effects in the bovine $\mathrm{CL}$ (Brown and Braden, 2001).

IGF-I Summary - Model of IGF-I action in the pig (Fig. 2)

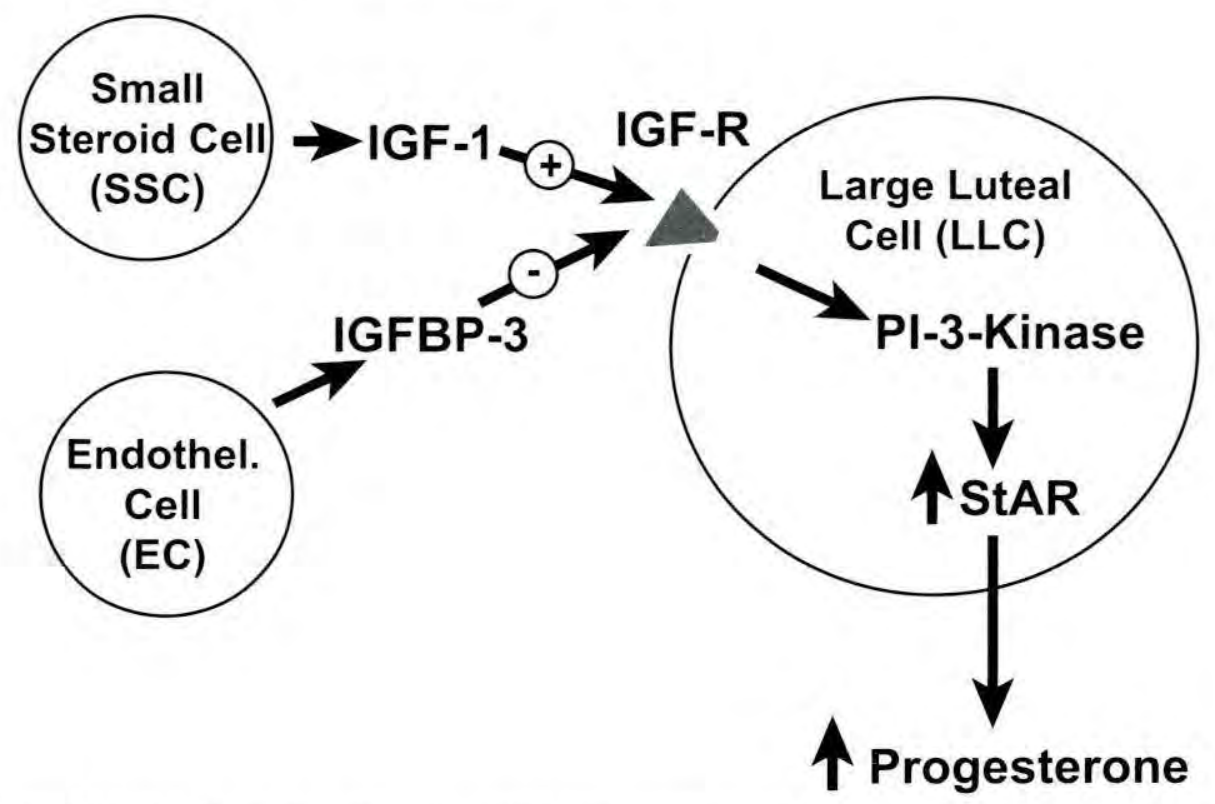

Fig. 2 Model illustrating the role of IGF-I in regulating the porcine CL during the "IGFsensitive period" ( $\sim$ days $4-7$ ). IGF-I originating from small luteal cells (probably steroidogenic; SSC) acts on IGF-R on large luteal cells (LLC) to activate the PI-3-kinase pathway and progesterone synthesis via increased StAR. IGBP-3 secreted from endothelial cells (EC) inhibits IGF-I binding to its receptor.

Overall, these data strongly suggest that during the IGF-I sensitive period (up to day 7), IGF-I (probably from small steroidogenic cells; SSC) has paracrine actions on large luteal cells (LLC) via IGF-IR, PI-3-kinase and up-regulation of StAR, to stimulate steroidogenesis. This model also 
illustrates how IGFBPs (e.g. BP-3) from endothelial cells (EC) act in a paracrine manner to inhibit the action of IGF-I on LLC. While our studies have focused on steroidogenesis, IGF-I also blocks apoptosis and stimulates cell proliferation in various cell types (Valentinis and Baserga, 2001) including ovarian steroidogenic cells (Chakravorty et al., 1993; Westfall et al., 2000; Ptak et al., 2004),

\section{Tumour necrosis factor- $\alpha$}

Tumour-necrosis factor (TNF)- $\alpha$ is a pro-inflammatory cytokine produced by resident tissue macrophages (MacEwan, 2002). Luteal macrophages accumulate in the $\mathrm{CL}$ towards the end of the oestrous cycle and thus the role of TNF- $\alpha$ in luteal regression has been studied extensively (Pate and Keyes, 2001).

\section{TNF- $\alpha$}

TNF- $\alpha$ mRNA expression did not vary as the oestrous cycle progressed in the bovine CL (Petroff et al., 1999; Sakumoto et al., 2000), but was elevated in response to PGF $_{2 \alpha}$ treatment at mid-cycle (Neuvians et al., 2004). TNF- $\alpha$ protein secretion increased in late luteal phase CLs (Sakumoto et al., 2000), and in CLs whose progesterone secretory activity had begun to decline (Shaw and Britt, 1995). Recently, the number of luteal macrophages (or monocytes) were found to increase significantly between early and mid (days 6-12) cycle, raising the possibility that in the cow these cells (or their cytokines) may have effects on the $\mathrm{CL}$ before luteolysis (Townson et al., 2002).

Likewise in the pig, the number of luteal macrophages secreting TNF- $\alpha$ increased most dramatically ( 4-fold) between the early (days 4-6) and mid (days 8-12) luteal phase, but also increased an additional 1-2 fold in the late luteal phase (days 14-18; Zhao et al., 1998), suggesting that TNF$\alpha$ may have effects prior to luteolysis in the pig also.

\section{TNF-receptors}

TNF- $\alpha$ acts on target cells via TNF-receptors (TNFR) type 1 or 2 . TNF- $\alpha$ can then activate multiple signalling pathways via the intracellular TNF-receptor associated factor (TRAF) proteins (MacEwan, 2002). Recent studies in the TNFR1 knockout mouse suggest that the luteolytic actions of TNF- $\alpha$ are mediated via TNFR1 (Roby et al., 1999).

TNFR1 mRNA concentrations in the bovine $\mathrm{CL}$ were unchanged during most of the oestrous cycle, but increased $\sim 3$ fold in regressing and PGF $_{2 \alpha}$-treated CLs (Friedman et al., 2000). TNFR1 was found in all luteal cell sub-types but was most highly expressed in endothelial cells (Okuda et al., 1999; Friedman et al., 2000). In another study in the cow, the expression of TNFR1 mRNA and protein were greatest during the early and mid-luteal phase CLs (days 3-12) and decreased in the late luteal phase CLs (Sakumoto et al., 2000).

TNF- $\alpha$ receptors have been detected on porcine small and large steroidogenic luteal cells as well as endothelial cells. Luteal TNF- $\alpha$ receptor levels remained unchanged between days 4 and 12 of the oestrous cycle, but increased on day 15 (Richards and Almond, 1994a; Miyamoto et al., 2002).

\section{TNF actions}

In general TNF- $\alpha$ 's effects on luteal steroidogenesis in the cow and pig are inhibitory (Pate and Keyes, 2001). However, while low doses of TNF- $\alpha$ induced luteolysis in vivo, high doses stimulated the CL and delayed luteolysis in cows (Skarzynski et al., 2003a). In pigs, TNF- $\alpha$ inhibited LH or hCG-stimulated progesterone secretion, mainly in small steroidogenic luteal cells (Pitzel et al., 
1993; Richards and Almond, 1994b; Pate and Keyes, 2001), although basal progesterone secretion by large luteal cells was also inhibited (Pitzel et al., 1993). In the rat, TNF- $\alpha$ inhibited luteal steroidogenesis via an inhibition of luteal LH receptor and StAR mRNA expression (Chen et al., 1999). In the pig, TNF- $\alpha$ has luteolytic actions because it inhibits oestradiol, which is luteotrophic in this species (Pitzel et al., 1993). TNF- $\alpha$ also stimulates prostaglandin (PGE ${ }_{2}$ PGF ${ }_{2 \alpha}$ and 6-ketoPGF $_{1 \alpha}$ ) production by bovine (Okuda et al., 1999; Sakumoto et al., 2000; Pate and Keyes, 2001) and porcine (Richards and Almond, 1994b; Miyamoto et al., 2002) luteal cells. It has been suggested that the luteolytic actions of TNF- $\alpha$ may be mediated by PGF $_{2 \alpha}$ in the pig (Richards and Almond, 1994b), but not in the cow (Pate and Keyes, 2001). In addition, TNF- $\alpha$ synergises with $\mathrm{PGF}_{2 \alpha}$ to promote functional luteolysis in the pig both in vitro and in vivo (Pitzel et al., 1993; Wuttke et al., 1998). Finally, TNF- $\alpha$ induced apoptosis of bovine luteal endothelial cells (Pru et al., 2003), an effect that could be prevented by treatment of cells with progesterone (Friedman et al., 2000). However, TNF- $\alpha$ was not cytotoxic to steroidogenic luteal cells except in combination with interferon (IFN)- $\gamma$ (Pate and Keyes, 2001).

TNF- $\alpha$ Summary - Models

A. Role of TNF- $\alpha$ in de-sensitising the porcine CL to IGF-I: As described above, porcine luteal cells lose their sensitivity to IGF-I on days 10-16 of the oestrous cycle, in spite of the elevated levels of IGF-IR on day 10 (Ge et al., 2000; Miller et al., 2003). Since the numbers and TNF- $\alpha$ secretory capacities of luteal macrophages increased $\sim 4$-fold during this period (Zhao et al., 1998), we hypothesised that TNF- $\alpha$ may play a role in de-sensitising porcine luteal cells to IGF-I in vivo. In support of this hypothesis, TNF- $\alpha$ has been shown to block IGF-I signalling pathways in several different cell types (Urban et al., 1996; Venters et al., 2000; Shalita-Chesner et al., 2001). In our studies (Fig. 3), TNF- $\alpha$ dose-dependently inhibited the steroidogenic actions of IGF-I on porcine luteal cells in culture.

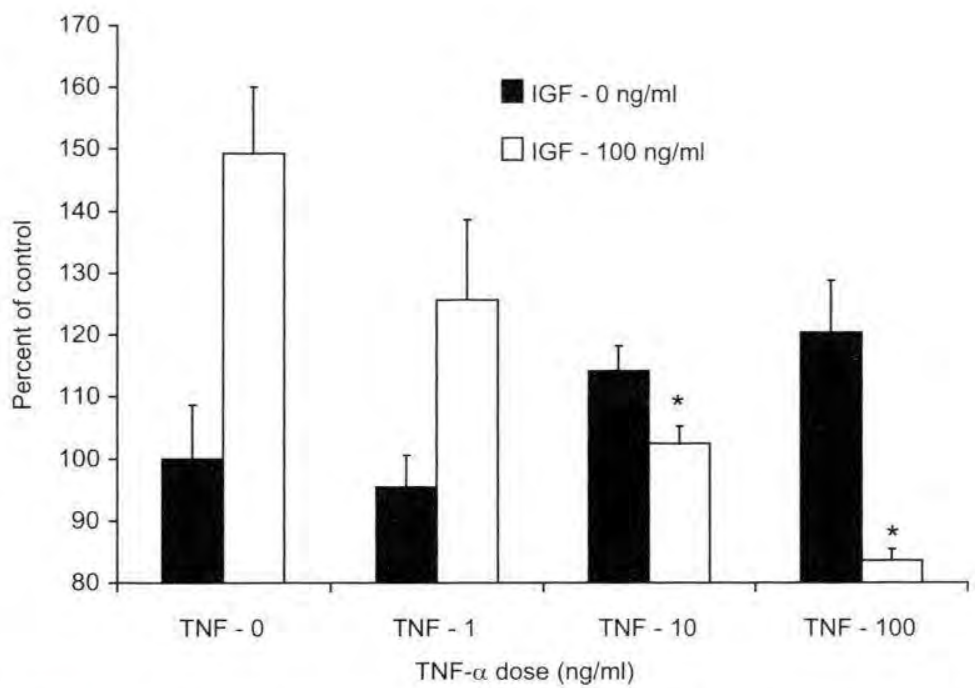

Fig. 3 Inhibitory actions of tumour necrosis factor (TNF)- $\alpha$ on IGF-I stimulated progesterone secretion by porcine luteal cells in vitro. Mixed porcine luteal cells (day 7 of cycle) were cultured with $0,1,10$ or $100 \mathrm{ng} / \mathrm{ml}(\mathrm{n}=6) \mathrm{TNF}-\alpha$, in the presence $(100 \mathrm{ng} / \mathrm{ml})$ or absence $(0$ $\mathrm{ng} / \mathrm{ml}$ ) of IGF-I. Data shown are representative of 3 separate experiments and are presented as progesterone concentrations, expressed as a percent of the control (no TNF- $\alpha$, no IGF-I) values. * Indicates significant difference ( $\mathrm{p}<0.05$; ANOVA) at 10 and $100 \mathrm{ng} / \mathrm{ml} \mathrm{TNF-} \alpha$ versus controls (no TNF- $\alpha$ ) in the presence of $100 \mathrm{ng} / \mathrm{ml} \mathrm{IGF-I.}$ 
Thus we propose a model (Fig. 4) in which macrophage-borne TNF- $\alpha$ decreases the sensitivity of porcine luteal cells to IGF-I, probably by blocking PI-3 kinase activation and up-regulation of StAR.

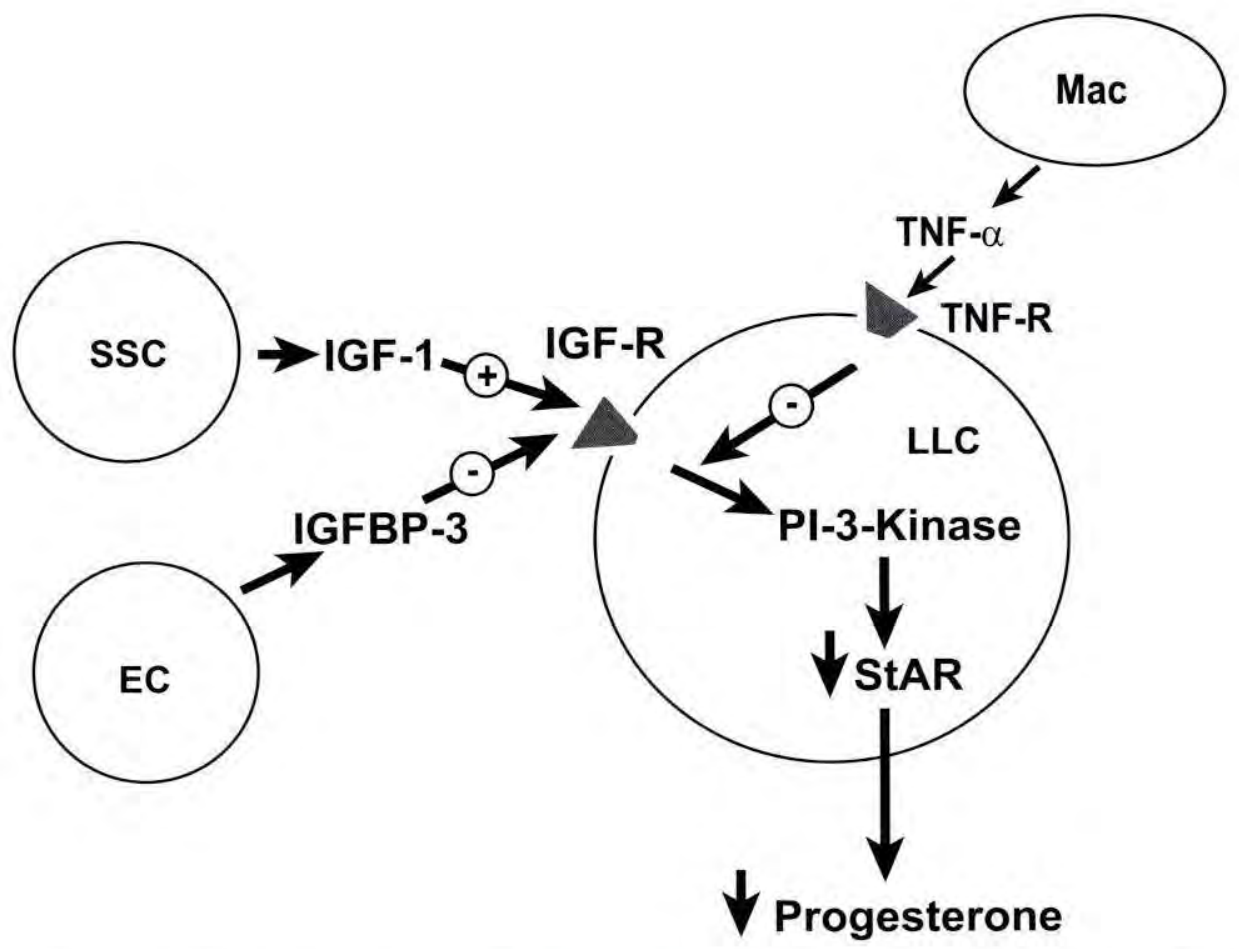

Fig. 4 Model illustrating the role of macrophage (Mac) - derived TNF- $\alpha$ in desensitising porcine luteal cells to IGF-I (between days 7-13). TNF- $\alpha$ acts via TNF-R on large luteal cells (LLC) to inhibit IGF-I actions at the post-receptor level (PI-3-kinase), leading to decreased StAR and progesterone secretion.

B. Role of TNF- $\alpha$ in sensitising the porcine $C L$ to $P G F_{2 \alpha}:$ In addition, since porcine CLs acquire luteolytic sensitivity (LS), during the IGF-insensitive period (days 10-16) we hypothesised that TNF- $\alpha$ may be involved in this process as well. To test this hypothesis, we examined whether priming of porcine luteal cells with TNF- $\alpha$ in vitro could increase their sensitivity to PGF ${ }_{2 \alpha}$. Porcine luteal cells were cultured with TNF- $\alpha$ for 2 days (days 2-4 of culture), and then were challenged with $1 \mathrm{ng} / \mathrm{ml} \mathrm{PGF}{ }_{2 \alpha}$ on days $4-6$ of culture. The data (Fig. 5) indicated that TNF- $\alpha$ sensitised luteal cells to the luteolytic actions of $\mathrm{PGF}_{2 \alpha}$. Since TNF- $\alpha$ increased ET- 1 secretion by luteal cells in vitro (Okuda et al.,1999; L. Rose and J. Gadsby, unpublished data), we hypothesise that ET-1 mediates the sensitising actions of TNF- $\alpha$. As suggested below this sensitising action of TNF- $\alpha / E T-1$ may involve up-regulation of protein kinase C (Fig. 6).

\section{Endothelin}

Endothelin-1

Endothelin (ET)-1 is a potent vasoconstrictive peptide originally described in the cardiovascular system, but which exerts important effects on the CL (Meidan and Levy, 2002). ET-1 is a 21 


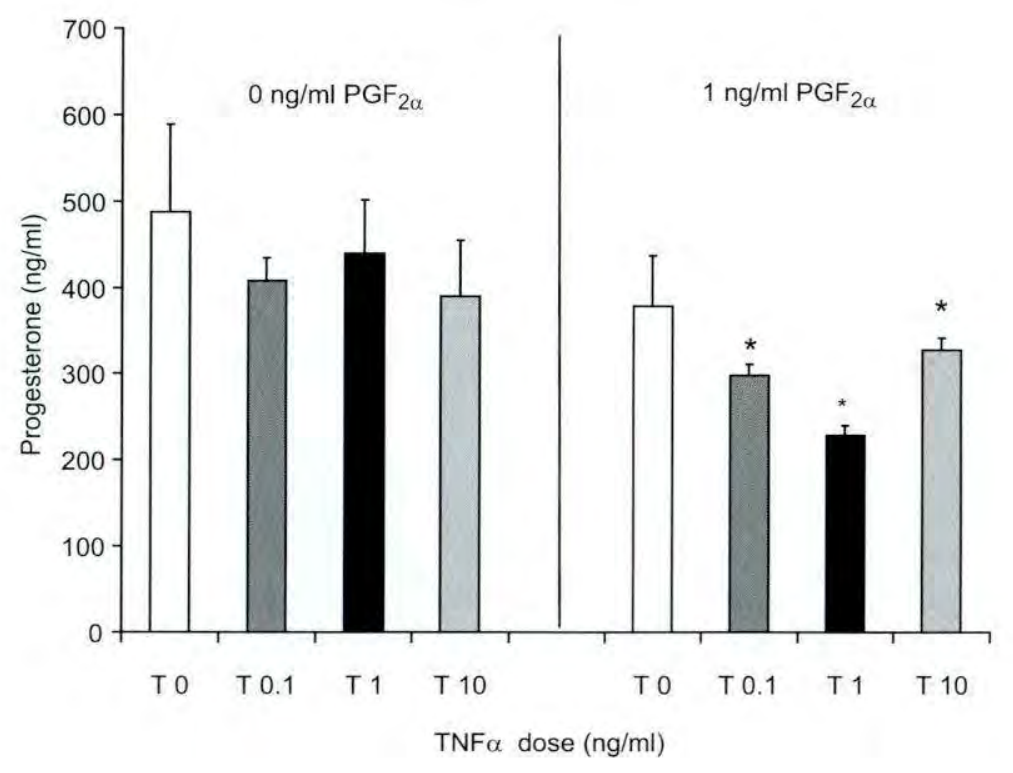

Fig. $5 \mathrm{TNF}-\alpha$ sensitises porcine luteal cells to $\mathrm{PGF}_{2 \alpha}$. Mixed porcine luteal cells (day 4 of cycle) were cultured for 2 days (days $2-4$ of culture) with $0,0.1,1$ or $10 \mathrm{ng} / \mathrm{ml}(n=6)$ TNF$\alpha$, and challenged with 0 or $1 \mathrm{ng} / \mathrm{ml} \mathrm{PGF}_{2 \alpha}$ for 2 days (days $4-6$ of culture). Data shown are representative of 3 separate experiments and are presented as $\mathrm{ng} / \mathrm{ml}$ progesterone (measured on day 6 of culture). ${ }^{*}$ Indicates significant difference $(p<0.05$; ANOVA) at $0.1,1$ and $10 \mathrm{ng} / \mathrm{ml} \mathrm{TNF}-\alpha$ versus controls $(\mathrm{no} T \mathrm{TNF}-\alpha)$ in the presence of $1 \mathrm{ng} / \mathrm{ml} \mathrm{PGF}_{2 \alpha}$.

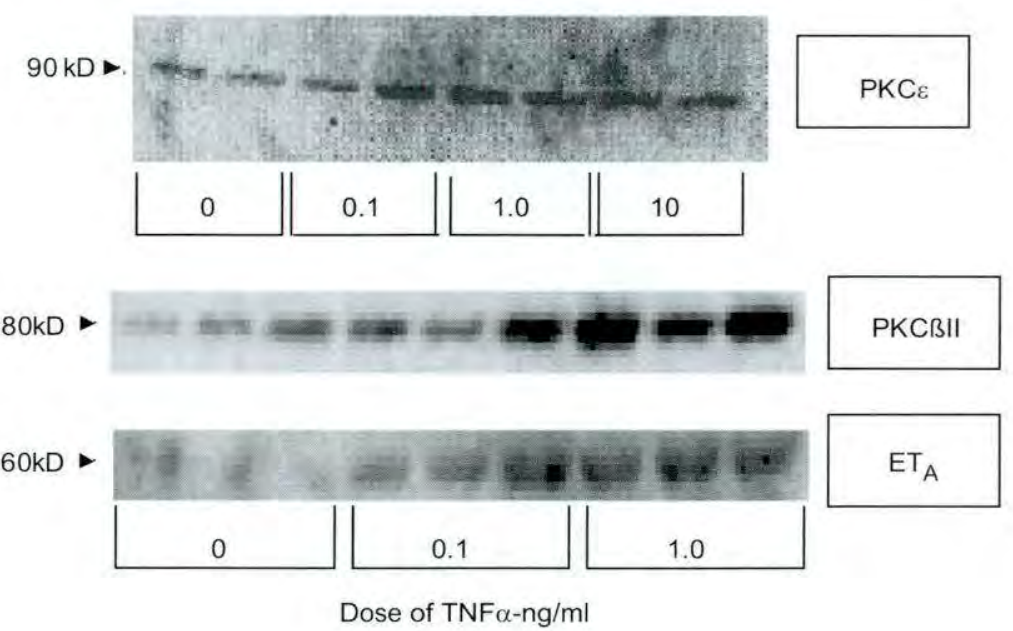

Fig. 6 TNF- $\alpha$ increases $\mathrm{PKC} \varepsilon, \mathrm{PKC} B \mathrm{II}$ and $\mathrm{ET}_{\mathrm{A}}$ protein expression in porcine luteal cells in culture. Porcine luteal cells were cultured as described in Fig. 5, cellular protein extracted on day 4 of culture and examined by Western blot. Data show PKCE, PKCßII and ET concentrations in response to TNF- $\alpha$ doses $(0,0.1,1$ or $10 \mathrm{ng} / \mathrm{ml} ; 2-3$ wells per treatment). 
amino acid (aa) peptide that is synthesised as part of the precursor protein, pre-pro (pp)-ET-1 (212 aa), and which is proteolytically cleaved (via an endopeptidase) to generate the biologically inert Big-ET-1 (38 aa). Big-ET-1 is cleaved by endothelin-converting enzyme (ECE)-1 to produce ET- 1 (Meidan and Levy, 2002).

In the cow, luteal ET-1 concentrations increased from the early to mid-luteal phase; this increase was thought to result from increased ECE-1 activity, since Big ET-1 concentrations declined at this time (Meidan and Levy, 2002). Expression of ppET-1 mRNA increased in the late luteal phase perhaps explaining increased ET-1 secretion during luteolysis (Meidan and Levy, 2002). In another study, ET-1 mRNA and peptide expression were high during the early luteal phase, declined in the mid and late luteal phase, and increased in regressing CLs (Berisha et al., 2002). It is not clear why these studies differed, but both showed an increase in ET-1 during luteal regression, pointing to its potential role in this process.

Endothelial cells are the primary source of ET-1 in the CL, as indicated by expression of ppET1 mRNA (Meidan and Levy, 2002; Davis et al., 2003; Klipper et al., 2004). Other luteal cell types are capable of cleaving ET-1 from Big-ET-1 via membrane associated ECE-1 (Meidan and Levy, 2002; Davis et al., 2003). The major regulators of ET-1 production are $\mathrm{PGF}_{2 \alpha}$ and TNF- $\alpha$. PGF $F_{2 \alpha}$ has been shown to increase ET-1 mRNA and peptide expression in ruminant CLs in vivo, and by luteal cells in vitro (Hinckley and Milvae, 2001; Wright et al., 2001; Meidan and Levy, 2002; Schams et al., 2003; Choudhary et al., 2004), although PGF $_{2 a}$ treatment was only effective in vivo in the mid-late luteal phase (cow - Meidan and Levy, 2002). Furthermore, PGF $_{2 \alpha}$ infused by microdialysis into the ovine or bovine CL, increased the release of ET-1 (Ohtani et al., 1998; 2004). TNF- $\alpha$ stimulates ET-1 secretion from bovine luteal endothelial cells (Okuda et al., 1999) and porcine luteal cells (L. Rose and J. Gadsby, unpublished data) in vitro.

\section{Endothelin-converting enzyme (ECE)-1}

There are four isoforms of ECE-1 (a-d) that differ in their amino terminal sequences, which probably accounts for their different sub-cellular localisations and thus different intracellular sites for ET-1 synthesis (from Big ET-1; Klipper et al., 2004). For example ECE-1a resides intracellularly, whereas ECE-1b is found on the cell membrane (Meidan and Levy, 2002). Steroidogenic luteal cell types express exclusively the ECE-1b isoform enabling these cells to generate bioactive ET-1 at the cell surface close to the ET-receptor (Meidan and Levy, 2002; Levy et al., 2003). Endothelial cells possess all ECE-1 isoforms suggesting that these cells can convert Big-ET-1 to ET-1 both intra- and extra-cellularly (Meidan and Levy, 2002; Levy et al., 2003; Klipper et al., 2004).

In one study in the bovine CL, ECE-1 (mRNA and protein) increased between the early and midluteal phases (Meidan and Levy, 2002; Levy et al., 2003). This increase in ECE-1 was hypothesised to account for the increase in ET-1 production between early and mid-luteal phases, and thus for the acquisition of LS in the bovine CL (Meidan and Levy, 2002). In other studies, ECE-1 mRNA expression levels were either reported to be relatively constant (Berisha et al., 2002), or to increase between the early and mid-luteal phases (Choudhary et al., 2004). In addition, while ECE1 protein (Western blot) concentrations decreased, ECE-1 enzyme activity ailed to show any significant changes during this period (Choudhary et al., 2004), casting some doubt on the proposed critical role of ECE-1 described above (Meidan and Levy, 2002; Levy et al., 2003). Little is known of the regulation of ECE-1 expression in the $\mathrm{CL}$, although there is a report suggesting that $\mathrm{PGF}_{2 \alpha}$ can transiently increase ECE-1 mRNA levels in the bovine CL (Schams et al., 2003). Other studies in the cow suggest that LH inhibits, and IGF-1 or insulin stimulates, ECE-1 in granulosalutein cells, and ET-1 inhibits ECE-1 mRNA expression in luteal cells, in vitro (Levy et al., 2003). 
Endothelin receptors and actions

There are two ET-receptor sub-types, $\mathrm{ET}_{\mathrm{A}}$ and $\mathrm{ET}_{\mathrm{B}^{\prime}}$, originally named after the location of their discovery (ET for aorta and $\mathrm{ET}_{\mathbf{B}}$ for bronchus; Meidan and Levy, 2002). These receptors belong to the superfamily of seven-transmembrane $G$ protein coupled receptors.

Based on ligand binding studies bovine CLs were shown to express ET-receptors, mainly the ET subtype (Meidan and Levy, 2002). All bovine luteal cell subtypes expressed ET mRNA, $_{\mathrm{A}}$ although the highest concentrations were seen in endothelial cells (Meidan and Levy, 2002); luteal endothelial cells were also found to express $\mathrm{ET}_{\mathrm{B}}$ (Klipper et al., 2004). ET $\mathrm{mRNA}$ concentrations in bovine CLs remained relatively constant from early to late stages of the oestrous cycle, but increased $\sim 2-5$-fold in regressing CLs (Meidan and Levy, 2002). The elevated expression of $E T_{A}$ in late stage CLs is consistent with an involvement of $E T-1$ in PGF $_{2 \alpha}$ - induced luteolysis (Hinckley and Milvae, 2001; Meidan and Levy, 2002). Another study in the cow showed no changes in $\mathrm{ET}_{A} \mathrm{mRNA}$ concentrations throughout the oestrous cycle but an increase in $\mathrm{ET}_{B}$ during $\mathrm{CL}$ regression was seen (Berisha et al., 2002). In an additional report, $\mathrm{ET}_{A}$ increased between early and mid-cycle, with a slight decline in the late cycle, while $\mathrm{ET}_{\mathrm{B}}$ increased in the early stages and thereafter remained constant throughout the cycle (Wright et al., 2001; Choudhary et al., 2004). There is no definitive explanation for the differences observed between these studies. $\mathrm{PGF}_{2 \alpha}$ up-regulates the expression of $\mathrm{ET}_{\mathrm{A}}$ MRNA in the bovine $\mathrm{CL}$, but only when administered in the mid-late luteal phase (Meidan and Levy, 2002; Schams et al., 2003; Choudhary et al., 2004). The effects of PGF ${ }_{2 \alpha}$ on ET $_{B}$ mRNA are more controversial, with one study showing an increase (Schams et al., 2003) and another study showing no effect (Choudhary et al., 2004). ET ${ }_{A}$ mRNA expression in luteal steroidogenic cells was negatively regulated during luteinisation; $\mathrm{LH}$ or Forskolin inhibited $\mathrm{ET}_{\mathrm{A}}$ by small (theca derived), whereas insulin or IGF-I inhibited ET ${ }_{\wedge}$ by large (granulosa derived) luteal cells in the cow (Meidan and Levy, 2002).

ET-1 decreased luteal progesterone secretion in vitro (Hinckley and Milvae, 2001; Meidan and Levy, 2002; Choudhary et al., 2005) and in vivo (Hinckley and Milvae, 2001; Ohtani et al., 2004), an effect which appears to be mediated via the $E T_{A}$ receptors (Hinckley and Milvae, 2001; Meidan and Levy, 2002). ET-1's vasoconstrictive actions are also probably mediated via $\mathrm{ET}_{\mathrm{A}}$ receptors on vascular smooth muscle cells of ovarian arterioles, and presumably play an important role during luteolysis by reducing blood flow to the CL (Klipper et al., 2004; Ohtani et al., 2004). In contrast, the $\mathrm{ET}_{\mathrm{B}}$ receptor subtype (Klipper et al., 2004) appears to mediate ET1 's action on nitric oxide production, which has vasodilatory effects (Klipper et al., 2004). How the balance of these opposing actions of ET-1 is achieved in the regressing $\mathrm{CL}$, is not currently known.

ET-1's actions via $\mathrm{ET}_{\mathrm{A}}$ are similar to those of $\mathrm{PGF}_{2 \alpha}$ via its receptor; activation of phospholipase C (PLC), release of intracellular calcium and activation of protein kinase C (PKC; SchmitzSpanke and Schipke, 2000). As discussed above, studies using the $\mathrm{ET}_{A}$ selective antagonists, have shown that the $\mathrm{ET}_{\mathrm{A}}$ receptor subtype mediates the luteolytic actions of $E T-1$ and $P G F_{2 a}$ in the CL (Hinckley and Milvae, 2001; Meidan and Levy, 2002). In addition, since PGF ${ }_{2 \alpha}$ also induces ET-1 production (see above), it is clear that interactions between these factors are critical to the luteolytic process in vivo. ET-1's actions via $\mathrm{ET}_{\mathbf{B}}$ on luteal endothelial cells appear to involve the stimulation of the inducible form of nitric oxide synthase (iNOS) leading to the generation of Nitric Oxide (NO; Klipper et al., 2004). Since NO also has been shown to be involved in $\mathrm{PGF}_{2 a}$ 's luteolytic actions (Skarzynski et al., 2003b), it is possible that ET-1 acting via $E_{B}$ may also be involved in $C L$ regression.

In ruminants, sub-luteolytic doses of $\mathrm{PGF}_{2 \alpha}$ given in the presence of ET- 1 in vivo will cause complete luteal regression, showing that ET-1 and PGF $_{2 \alpha}$ act synergistically (Hinckley and Milvae, 2001). A similar synergistic response was demonstrated for TNF- $\alpha$ and $\mathrm{PGF}_{2 \alpha}$ in the pig 
in vitro (Pitzel et al., 1993) and in vivo using CL microdialysis (Wuttke et al., 1998). In our preliminary studies (Fig. 5), we have demonstrated that TNF- $\alpha$ "sensitised" porcine luteal cells in vitro to the luteolytic effects of $\mathrm{PGF}_{2 \alpha^{\circ}}$ In view of the fact that TNF- $\alpha$ increases ET-1 secretion by endothelial cells (Okuda et al., 1999) and porcine luteal cells (L. Rose and J. Gadsby, unpublished data), and that TNF- $\alpha$ dose-dependently increased $\mathrm{ET}_{\mathrm{A}}$ expression on porcine luteal cells (Fig. 6), we hypothesise that ET-1 mediates TNF- $\alpha$ 's role in inducing LS in the porcine CL during the oestrous cycle (see below).

\section{PGF $_{2 \alpha}$ luteolytic sensitivity (LS) and luteolysis}

In order to understand the roles of TNF- $\alpha$ and/or ET-1 in the regulation of LS in the pig, it is critical to review the topic of $\mathrm{LS}$ and the role of $\mathrm{PGF}_{2 \alpha}$ in the process of luteolysis.

In ruminants, the early $\mathrm{CL}$ displays a period of insensitivity to $\mathrm{PGF}_{2 \alpha}$ (i.e. lacks $L S$ ) that lasts $~ 5$ 6 days (see Estill et al., 1995 for refs). After this period, CLs display LS and thus PGF $_{2 \alpha}$ or its analogues will cause premature luteal regression and shortening of the oestrous cycle (see Estill et al., 1995 for refs; Meidan and Levy, 2002). Several theories have been proposed for the mechanism of LS in ruminants: 1) only CLs displaying LS respond to $\mathrm{PGF}_{2 \alpha}$ by up-regulating the luteal cycloxygenase (COX)-2 enzyme, leading to increased intra-luteal $P \mathrm{PF}_{2 \alpha}$ production, which appears necessary for luteolysis (Diaz et al., 2002); 2) only CLs displaying LS (mid-cycle) have elevated ET-1 levels (discussed above - Meidan and Levy, 2002); 3) CLs lacking LS (early) showed elevated levels of PGF $_{2 \alpha}$ metabolism compared with those at mid-cycle (Silva et al., 2000); and 4) protein kinase (PK) $C_{-} \varepsilon$ specifically, is up-regulated in bovine $\mathrm{CLS}_{s}$ that display $\mathrm{LS}$ and it is this PKC isoform that mediates $\mathrm{PGF}_{2 \alpha}$ luteolytic signalling in vitro (Sen et al., 2004; 2005).

The pig is unusual since $\mathrm{CLs}$ are insensitive to the luteolytic actions of $\mathrm{PCF}_{2 \alpha}$ (i.e. lack LS) until after day 12 of the oestrous cycle (see Estill et al., 1993 for refs). Consequently, PGF ${ }_{2 \alpha}$ analogues cannot be used to shorten the oestrous cycle (Estill et al., 1993). Our original studies designed to address this problem measured the luteal $\mathrm{PGF}_{2 \alpha}$ (FP) receptor, and we showed a $\sim 3$ fold increase on days 13-14 (vs. days 4-12; Gadsby et al., 1990; 1993), coinciding with the onset of LS in this species (Estill et al., 1993; 1995). Recently we found that PGF ${ }_{2 \alpha}$-receptor mRNA levels were significantly elevated on day 10 , reaching a maximum on day 13 of the oestrous cycle (Boonyaprakob et al., 2003). However, important functional differences between CLs lacking and those possessing $L S$, probably occur at the post-FP receptor level, as suggested by the following studies. Previously it was shown that repeated administration of $\mathrm{PGF}_{2 \alpha}$ analogues (Lutalyse and Cloprostenol) on days 5-10 of the oestrous cycle, induced premature luteolysis and shortened cycle length by up to 7 days (Estill et al., 1993; 1995; Gadsby et al., 1996b). These studies indicated that LS can be advanced in the pig, although this occurred without an increase in FP receptors (Estill et al., 1995). In another study Cloprostenol administration induced COX-2 (mRNA and protein) in both CLs lacking (day 9 of oestrous cycle), and displaying (day 17 of pseudopregnancy), LS (Diaz et al., 2000). However, Cloprostenol did not increase $\mathrm{PGF}_{2 \alpha}$ or decrease progesterone secretion on day 9 , whereas it did significantly increase PGF $_{2 \alpha}$ and decreased luteal progesterone secretion on day 17 (Diaz et al., 2000). Furthermore, the PKC-activator (PDD) was found to be equally capable of increasing luteal $\mathrm{PGF}_{2 \alpha}$ synthesis on days 9 and 17, but was less effective at decreasing progesterone secretion on day 9 compared with day 17 (Diaz et al., 2000). These data suggested that: 1) protein kinase $C$ levels may be rate-limiting to the luteolytic actions of PGF 2 in CLs which lack $\mathrm{LS}$; and 2) $\mathrm{PGF}_{2 \alpha}$ and progesterone synthetic pathways may be regulated by different PKC-isoforms (Diaz et al., 2000).

$\mathrm{PGF}_{2 \alpha}$ acts on the $\mathrm{CL}$ to stimulate phospholipase-C leading to the generation of inositol triphosphate (IP-3) and diacylglycerol (DAG); IP-3 in turn increases intracelluar $\mathrm{Ca}^{2+}$ levels and DAG activates several isoforms of protein kinase $C$, specifically PKC- $\alpha, \beta I, \beta I I, \varepsilon$ and $\theta$ in inducing 
functional luteolysis (Davis et al., 1996; Chen et al., 2001; Diaz et al., 2002; Sen et al., 2005). The PKC isoforms have been classified based on their mode of activation: 1) PKC- $\alpha, \beta I, \beta I I$ and $\gamma$, which depend on calcium, DAG, and phosphatidylserine (PS) for activation ("classical or conventional PKCs"); 2) PKC-isoforms $\delta, \varepsilon, \eta, \mu$ and $\theta$, that are independent of calcium, but which require DAG and PS ("novel PKCs"); 3) PKC-isoforms $\zeta$ and $\nu \lambda$, which only require PS ("atypical PKCs"); and 4) a new structurally distinct type of PKC isoform called "PKC-related kinases", that also require only PS (DaRocha et al., 2002).

As discussed above in the porcine $\mathrm{CL}, \mathrm{PKC}$ levels appear to be limiting to $\mathrm{PGF}_{2 \alpha}$ 's actions leading us to hypothesise that the activities of PKC (e.g. $\alpha, \beta I, B I I, \varepsilon$ or $\theta$ ) will increase during the acquisition of $L S$, and will be elevated in response to TNF- $\alpha$ (via ET-1). In preliminary studies we showed that TNF- $\alpha$ up-regulated PKC-BII and PKC- $\varepsilon$ (Fig. 6) in cultured porcine luteal cells (in vitro) implicating these isoforms at least, in the $\mathrm{PGF}_{2 \alpha}$ sensitisation process, as suggested for the bovine CL (Sen et al., 2004; 2005).

\section{Overall model for the acquisition of $L S$}

Fig. 7 shows a model illustrating our hypotheses concerning the roles of TNF- $\alpha$ and ET- 1 in regulating LS in the pig. TNF- $\alpha$ originating from macrophages, stimulates endothelial cells to secrete ET-1 (Okuda et al., 1999; L. Rose and f. Gadsby, unpublished data). ET-1 acts via ET on large luteal cells to increase PKC expression PKC-BII and $-\varepsilon$ (Fig. 6), to mediate the increased LS of luteal cells to PGF ${ }_{2 \alpha^{*}}$. This model represents fundamentally new thinking about the roles of TNF- $\alpha$ and ET-1 as factors which sensitise luteal cells to PGF ${ }_{2 \alpha}$ and is under current examination in our efforts to understand the control of LS in the pig.

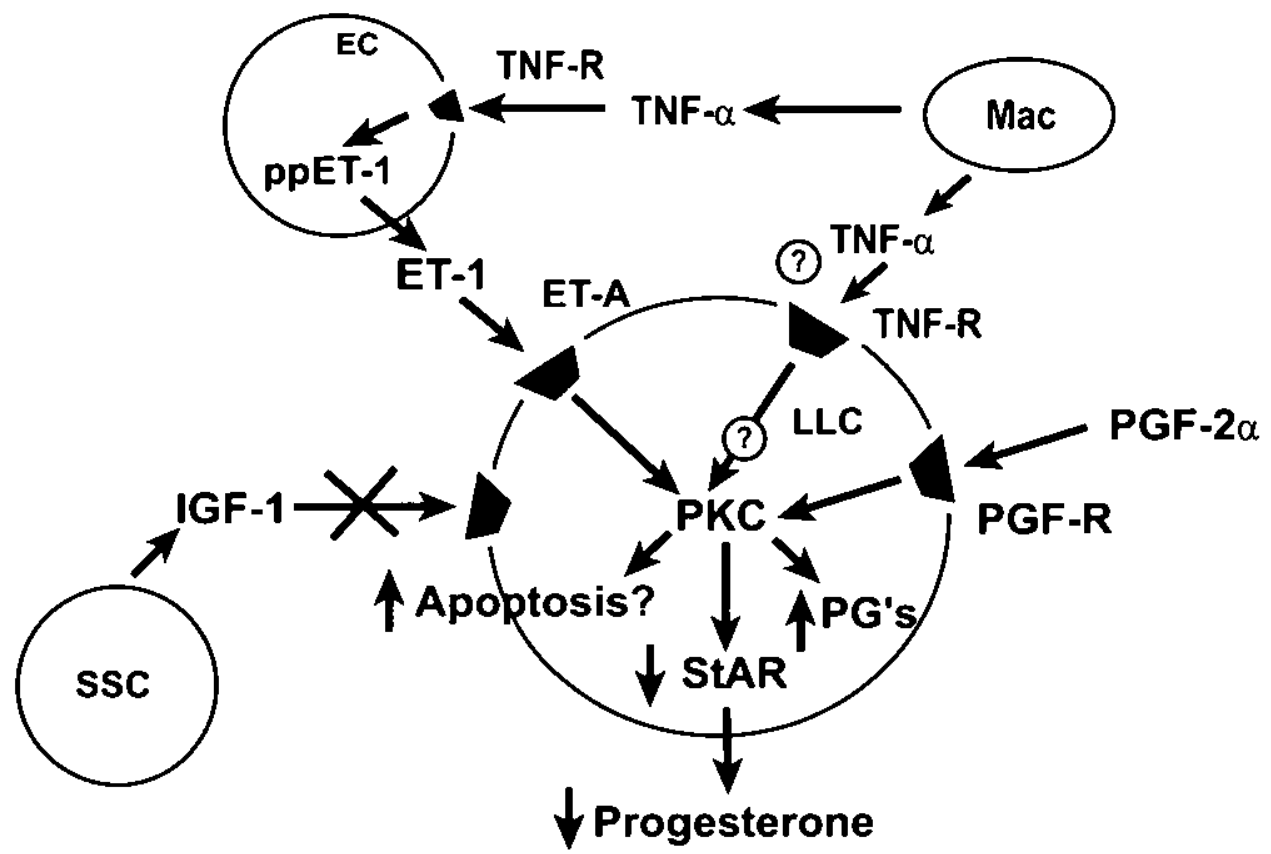

Fig. 7 Model illustrating the role of macrophage (Mac) - derived TNF- $\alpha$ in sensitising porcine luteal cells to $\mathrm{PGF}_{2 \alpha}$ (between days 7-13). TNF- $\alpha$ acts via TNF-R on endothelial cells (EC) to increase ET-1 production. ET-1 acts via ET ${ }_{A}$ receptors on LLC to increase PKC isoform expression (e.g. PKCßII or PKCE), which increases LLC sensitivity to $\mathrm{PGF}_{2 \alpha}$ at a post- receptor (FP) level, leading to decreased StAR, decreased progesterone and increased prostaglandin (PG) production, and possibly increased apoptosis. 


\section{Acknowledgments}

We gratefully acknowledge funding from the USDA Cooperative State Research, Education, and Extension Service (NRICG's 1998-35203-6283 and 2004-35203-14777), the North Carolina Pork Producers Association, USDA Animal Health Formula Funds, and funds from the State of North Carolina, to support this research. We also acknowledge Brenda L. Bunch, Biomedical Iflustrator, NC State University, College of Veterinary Medicine for creating the illustrations oNCSU-CVM, 2005.

\section{References}

Amselgruber W, Sinowatz F, Schams D and Skottner A (1994) Immunohistochemical aspects of insulin-like growth factors I and II in the bovine corpus luteum journal of Reproduction and Fertility $101445-451$

Anderson LL, Dyck GW, Mori H, Henricks DM and Melampy RM (1967) Ovarian function in pigs following hypophysial stalk section or hypophysectomy American lournal of Physiology 212 1188-1194

Balasubramanian K, Lavoie HA, Garmey IC, Stocco DM and Veldhuis JD (1997) Regulation of porcine granulosa cell steroidogenic acute regulatory protein (StAR) by insulin-like growth factor I: synergism with follicle stimulating hormone or protein kinase $A$ agonist Endocrinology 138 433-439

Baxter RC (2000) Insulin-like growth factor (IGF)-binding proteins: interactions with IGFs and intrinsic bioactivities American lournal of Physiology 278 E967. 976

Berisha B, Schams D and Miyamoto A (2002) The expression of angiotensin and endothelin system members in bovine corpus luteum during estrous cycle and pregnancy Endocrine 19 305-312

Boonyaprakob U, Gadsby JE, Hedgpeth V, Routh $P$ and Almond GW (2003) Cloning of a porcine prostaglan$\operatorname{din} F_{2 \alpha}$ (FP) receptor cDNA and the expression of its mRNA in the corpora lutea Reproduction 125 53-64

Brown TA and Braden TD (2001) Expression of insulinlike growth factor binding protein (IGFBP)-3, and the effects of ICFBP-2 and -3 in the bovine corpus luteum Domestic Animal Endocrinology 20 203-216

Chakravorty A, Joslyn MI and Davis JS (1993) Characterization of insulin and insulin-like growth factor-I actions in the bovine luteal cell: regulation of receptor tyrosine kinase activity, phosphatidylinositol-3-kinase, and deoxyribonucleic acid synthesis Endocrinology 133 1331-1340

Chen D, Fong HW and Davis IS (2001) Induction of c-fos and c-jun messenger ribonucleic acid expression by prostaglandin $\mathrm{F}_{2 \alpha}$ is mediated by a protein kinase $\mathrm{C}$ dependent extracellular signal-regulated kinase mitogen-activated protein kinase pathway in bovine luteal cells Endocrinology 142 887-895

Chen Y-J, Feng $Q$ and Liu Y-X (1999) Expression of the steroidogenic acute regulatory protein and luteinizing hormone receptor and their regulation by tumor necrosis factor- $\alpha$ in rat corpora lutea Biology of Reproduction $60410-427$
Choudhary E, Costine BA, Wilson ME, Inskeep EK and Flores JA (2004) Prostaglandin $F_{2 a}\left(P_{2 a}\right)$ independent and dependent regulation of the bovine luteal endothelin system Domestic Animal Endocrinology $2763-79$

Choudhary E, Sen A, Inskeep EK and Flores JA (2005) Developmental sensitivity of the bovine corpus luteum to prostaglandin $F_{2 a}\left(\mathrm{PGF}_{2 a}\right)$ and endothelin-1 (ET-1):Is ET-1 a mediator of the luteolytic actions of PGF or a tonic inhibitor of progesterone secretion? Biology of Reproduction 72 633-642

DaRocha AB, Mans DRA, Regner A and Schwartsmann G (2002) Targeting protein kinase C: new therapeutic opportunities against high-grade malignant gliomas? The Oncologist 7 17-33

Davis IS, May IV.and Keel BA (1996) Mechanisms of hormone and growth factor action in the bovine corpus luteum Theriogenology 45 1351-1380

Davis JS, Rueda BR and Spanel-Borowski K (2003) Microvascular endothelial cells of the corpus luteum Reproductive Biology and Endocrinology 1 89-103

Diaz FJ, Crenshaw TD and Wiltbank MC (2000) Prostaglandin $F_{2 a}$ induces distinct physiological responses in porcine corpora lutea after acquisition of luteolytic capacity Biology of Reproduction 63 1504-1512

Diaz FJ, Anderson LE, Wu YL, Rabot A, Tsai SI and Wiltbank MC (2002) Regulation of progesterone and prostaglandin $F_{2 \alpha}$ production in the CL Molecular and Cellular Endocrinology $19165-80$

Einspanier R, Miyamoto A, Schams D, Muller $M$ and Brem G (1990) Tissue concentration, mRNA expression and stimulation of IGF-I in luteal tissue during the oestrous cycle and pregnancy of cows journal of Reproduction and Ferility 90 439-445

Estill CT, Britt JH and Cadsby JE (1993) Repeated administration of prostaglandin $F_{2 a}$ during the early luteal phase causes premature luteolysis in the pig Biology of Reproduction 49 181-185

Estill CT, Britt JH and Gadsby JE (1995) Does increased $\mathrm{PGF}_{2 \mathrm{a}}$ receptor concentrations mediate $\mathrm{PGF}_{2 \mathrm{a}}$-induced luteolysis during early diestrus in the pig? Prostaglandins 49 255-267

Friedman A, Weiss S, L.evy N and Meidan R (2000) Role of tumor necrosis factor $\alpha$ and its type I receptor in luteal regression: induction of programmed cell death in bovine corpus luteum-derived endothelial cells Biology of Reproduction 63 1905-1912 
Gadsby JE, Balapure AK, Britt JH and Fitz TA (1990) Prostaglandin $F_{2 a}$ receptors on enzyme-dissociated pig luteal cells throughout the estrous cycle Endocrinology $126787-795$

Gadsby JE, Lovdal JA, Britt JH and Fitz TA (1993) Prostaglandin $F_{2 \alpha}$ receptor concentrations in corpora lutea of cycling, pregnant and pseudopregnant pigs. Biology of Reproduction 49 604-608

Gadsby JE, Grafinger M and Almond G (1996b) Shortcycling of gilts with prostaglandin analogs. In: Proceedings of the 14th International Pig Veterinary Society Congress, Bologna, italy, pp 564

Gadsby JE, Lovdal JA, Samaras S, Barber JS and Hammond IM (1996a) Expression of messenger ribonucleic acids for Insulin-like Growth Factor-l and Insulin-like Growth Factor Binding Proteins in porcine corpora lutea Biology of Reproduction 54 339-346

Ge Z, Nicholson WE, Plotner DM, Farin CE and Gadsby JE (2000) Insulin-like growth factor I receptor mRNA and protein expression in porcine corpora lutea fournal of Reproduction and Fertility 120 109-114

Ge Z, Miller E, Nicholson W, Hedgpeth V and Gadsby JE (2003) insulin-like growth factor (IGF)-I and IGF binding proteins $-2,-3,-4,-5$ in porcine corpora lutea during the estrous cycle; evidence for inhibitory actions of IGFBP-3 Domestic Animal Endocrinology 25 183-197.

Hinckley ST and Milvae RA (2001) Endothelin-1 mediates prostaglandin $\mathrm{F}_{2 \mathrm{a}}$-induced luteal regression in the ewe Biology of Reproduction 64 1619-1623

Juengel JL, Nett TM, Anthony RV and Niswender GD (1997) Effects of luteotrophic and luteolytic hormones on expression of mRNA encoding insulin-like growth factor-I and growth hormone receptor in the ovine corpus luteum lournal of Reproduction and Fertility $110 \quad 291-298$

Klipper E, Gilboa T, Levy N, Kisliouk T, Spanel-Borowski $K$ and Meidan R (2004) Characterization of endothelin-1 and nitric oxide generating systems in corpus luteum-derived endothelial cells Reproduction 128 $463-473$

Levy N, Gordin M, Smith MF, Bolden-Tiller OU and Meidan R (2003) Hormonal regulation and cell-specific expression of endothelin-converting enzyme 1 isoforms in bovine ovarian endothelial and steroidogenic cells Biology of Reproduction 68 13611368

Mamluk R, Greber Y, and Meidan R (1999) Hormonal regulation of messenger ribonucleic acid expression for steroidogenic factor-1, steroidogenic acute regulatory protein, and cytochrome $\mathbf{P 4 5 0}$ side-chain cleavage in bovine luteal cells Biology of Reproduction 60 628-634

MacEwan DJ (2002) TNF receptor subtype signalling: differences and cellular consequences Cellular Signalling 14 477-492

Meidan R and Levy N (2002) Endothelin-1 receptors and biosynthesis in the corpus luteum; Molecular and physiological implications Domestic Animal Endocrinology 23 287-298

Miller EA, Ge Z, Hedgpeth V and Gadsby JE (2003)
Steroidogenic responses of porcine corpora lutea to IGF-I in vitro and in vivo: involvement of the Pl-3kinase pathway Reproduction 125 241-249

Miyamoto $Y$, Sakumoto R, Sakabe $Y$, Miyake M, Okano $A$ and Okuda K (2002) Tumour necrosis factor- $\alpha$ receptors are present in the corpus luteum throughout the oestrous cycle and during the early gestation period in pigs Reproduction of Domestic Animals 37 $105-110$

Neuvians TP, Schams D, Berisha B and Pfaffl MW (2004) Involvement of pro-inflammatory cytokines, mediators of inflammation, and basic fibroblast growth factor in prostaglandin $\mathrm{F}_{\mathbf{2 a}}$ induced luteolysis in bovine corpus luteum Biology of Reproduction 70 473-480

Nicholson WE, Ge Z, Plotner DM, Farin CE and Gadsby JE (1999) Insulin-like growth factor (IGF)-I, IGF-I receptor and IGF binding protein-3 messenger ribonucleic acids and protein in corpora lutea from prostaglandin $\mathrm{F}_{2 a}$-treated gilts Biology of Reproduction 61 1527-1534

Ohtani M, Kobayashi S, Miyamoto A, Hayashi $K$ and Fukui $Y$ (1998) Real-time relationships between intraluteal and plasma concentrations of endothelin, oxytocin, and progesterone during prostaglandin $\mathrm{F}_{2 \alpha^{-}}$ induced luteolysis in the cow Biology of Reproduction 58 103-108

Ohtani M, Takase S, Wijayagunawardane MPB, Tetska $M$ and Miyamoto A (2004) Local interaction of prostaglandin $F_{2 a}$ with endothelin-1 and tumor necrosis factor $-\alpha$ on the release of progesterone and oxytocin in ovine corpora lutea in vivo: a possible implication for a luteolytic cascade Reproduction 127 117124

Okuda K, Sakumoto R, Uenoyama Y, Berisha B, Miyamoto A and Schams D (1999) Tumor necrosis factor $-\alpha$ receptors in microvascular endothelial cells from bovine corpus luteum Biology of Reproduction 61 1017.1022

Pate JL and Keyes PL. (2001) Immune cells in the corpus luteum; friends or foes? Reproduction 122 665-676

Petroff MG, Petroff BK and Pate JL (1999) Expression of cytokine messenger ribonucleic acids in the bovine corpus luteum Endocrinology 140 1018-1021

Pitzel L, Jarry $H$ and Wuttke $W$ (1993) Effects and interactions of prostaglandin $F_{z a^{\prime}}$ oxytocin and cytokines on steroidogenesis of porcine luteal cells Endocrinology 132 751-756

Pru JK, Lynch MP, Davis IS and Rueda BR (2003) Signaling mechanisms in tumor necrosis factor alpha-induced death of microvascular endothelial cells of the corpus luteum Reproductive Biology and Endocrinology 117.

Ptak A, Gregoraszczuk EL and Rzasa I (2003) Growth hormone and insulin-like growth factor-I action on progesterone secretion by porcine corpora lutea isolated at various periods of the luteal phase Acta Veterinaria Hungarica 51 197-208

Ptak A, Kajta M, Gregoraszczuk EL (2004) Effect of growth hormone and insulin-like growth factor-I on spontaneous apoptosis in cultured luteal cells collected from early, mature, and regressing porcine corpora lutea 
Animal Reproduction Science 80 267-279

Richards RG and Almond CW (1994a) Identification and distribution of fumor necrosis factor $\alpha$ receptors in pig corpora lutea Biology of Reproduction 51 12851291

Richards RG and Almond GW (1994b) Tumor necrosis factor- $\alpha$ differentially alters progesterone and prostaglandin- $\mathrm{F}_{2 a}$ production by porcine luteal cells Journal of Endocrinology 143 75-83

Roby KF, Son DS and Terranova PF (1999) Alterations of events related to ovarian function in tumor necrosis factor receptor type I knockout mice Biology of Reproduction 61 1616-1621

Sakumoto R, Berisha B, Kawate N, Schams D and Okuda, K (2000) Tumor necrosis factor- $\alpha$ and its receptors in bovine corpus luteum throughout the estrous cycle Biology of Reproduction 62 192-199

Sauerwein $H$, Miyamoto A, Gunther J, Meyer HHD and Schams D (1992) Binding and action of insulin-like growth factors and insulin in bovine luteal tissue during the oestrous cycle lournal of Reproduction and Fertility 96 103-115

Schams D, Berisha B, Kosmann $M$ and Amselgruber $W$ $M$ (2002) Expression and localization of IGF family members in bovine antral follicles during final growth and in luteal tissue during different stages of estrous cycle and pregnancy Domestic Animal Endocrinology 22 51-72

Schams D, Berisha 8, Neuvians T, Amselgruber $W$ and Kraetzl W-D (2003) Real-time changes of the local vasoactive peptide systems (angiotensin, endothelin) in the bovine corpus luteum after induced luteal regression Molecular Reproduction and Development $6557-66$

Schmitz-Spanke S and Schipke JD (2000) Potential role of endothelin-1 and endothelin antagonists in cardiovascular diseases Basic Research in Cardiology 95 290-298

Sen A, Browning J, Inskeep EK, Lewis P and Flores JA (2004) Expression and activation of protein kinase $C$ isozymes by prostaglandin $F_{2 a}$ in the early and midluteal phase bovine $\mathrm{CL}$ Biology of Reproduction 70 379-384

Sen A, Choudhary E, Inskeep EK and Flores JA (2005) Effects of selective protein kinase $C$ isozymes in prostaglandinF $\mathrm{Fa}_{2 \mathrm{i}}$-induced $\mathrm{Ca}^{2}$ signaling and luteinizing hormone-induced progesterone accumulation in the mid-phase bovine corpus luteum Biology of Reproduction 72 976-984

Shalita-Chesner M, Katz J, Shemer J and Werner H (2001) Regulation of insulin-like growth factor-l receptor gene expression by tumor-necrosis factor- $\alpha$ and interferon- $\gamma$ Molecular and Cellular Endocrinology 176 1.12

Shaw DW and Britt JH (1995) Concentrations of tumor necrosis factor $\alpha$ and progesterone within the bovine corpus luteum sampled by continuous-flow microdialysis during luteolysis in vivo Biology of Reproduction 53 847-854

Silva PJ, Juengel JL, Rollyson MK and Niswender GD (2000) Prostaglandin metabolism in the ovine cor- pus luteum: catabolism of prostaglandin $F_{2 \alpha}\left(\mathrm{PGF}_{2 \alpha}\right)$ coincides with resistance of the corpus luteum to PGF $_{2 a}$ Biology of Reproduction 63 1229-1236

Skarzynski DJ, Bah MM, Deptula KM, Woclawek-Potocka I, Korzekwa A, Shibaya M, Pilawski W and Okuda K (2003a) Roles of tumor necrosis factor- $\alpha$ on the estrous cycle in cattle: an in vivo study Biology of Reproduction 69 1907-1913

Skarzynski DJ, Jaroszewski J, Bah MM, Deptula KM, Barszczewska B, Gawronska B and Hansel W (2003b) Administration of a nitric oxide synthase inhibitor counteracts prostaglandin F2-induced luteolysis in cattle Biology of Reproduction 681674 1681

Townson DH, O'Connor CL and Pru JK (2002) Expression of monocyte chemoaltractant protein- 1 and distribution of immune cell populations in the bovine corpus luteum throughout the estrous cycle Biology of Reproduction 66 361-366

Urban RJ, Nagamani M and Bodenburg Y (1996) Tumor necrosis factor- $\alpha$ inhibits transcriptional activity of the porcine P-45011A insulin-like growth factor response element fournal of Biological Chemistry 271 31699-31703

Valentinis B and Baserga R (2001) IGF-I receptor signalling in transformation and differentiation Journal of Clinical Pathology: Molecular Pathology 54 133-137

Venters HD, Dantzer R and Kelley KW (2000) Tumor necrosis factor-alpha induces neuronal death by silencing survival signals generated by the type I insulin-like growth factor receptor Annals of the New York Academy of Sciences 917 210-220

Wandji S-A, Gadsby JE, Simmen FA, Barber JA and Hammond JH (2000) Porcine ovarian cells express messenger ribonucleic acids for the acid-labile subunit and insulin-like growth factor binding protein-3 during follicular and luteal phases of the estrous cycle Endocrinology 141 2638-2647

Westfall SD, Hendry IR, Obholz KL, Rueda BR and Davis IS (2000) Putative role of the phosphatidylinositol 3kinase - Akt signaling pathway in the survival of granulosa celts Endocrine 12 315-321

Wright MF, Sayre B, Inskeep EK and Flores JA (2001) Prostaglandin $F_{2 a}$ regulation of the bovine corpus luteum endothelin system during the early and midluteal phase Biology of Reproduction 651710 1717

Wuttke W, Spiess S, Knoke I, Pitzel L, Leonhardt S and Jarry H (1998) Synergistic effects of prostaglandin $F_{2 u}$ and tumor necrosis factor to induce luteolysis in the pig Biology of Reproduction 58 1310-1315

Yuan $W$ and Lucy MC (1996) Effects of growth hormone, prolactin, insulin-like growth factors and gonadotropins on progesterone secretion by porcine luteal cells Journal of Animal Science $74866-872$

Zhao Y, Burbach JA, Roby KF, Terranova PF and Brannian JD (1998) Macrophages are the major source of tumor necrosis factor- $\alpha$ in the porcine corpus luteum Biology of Reproduction 59 1385-1391 